\title{
CONTRIBUTIONS ON FORMULATION AND PRELIMINARY EVALUATION OF OCULAR COLLOIDAL SYSTEMS OF CHITOSAN AND POLOXAMER 407 WITH BUPIVACAINE HYDROCHLORIDE
}

\author{
TEODORA IRIMIA, GABRIELA CORNELIA MUŞAT *, RĂZVAN MIHAI PRISADA, MIHAELA \\ VIOLETA GHICA, CRISTINA ELENA DINU-PÎRVU, VALENTINA ANUŢA, BRUNO ŞTEFAN \\ VELESCU, LĂCRĂMIOARA POPA
}

“Carol Davila” University of Medicine and Pharmacy Bucharest, 37, Dionisie Lupu Street, 020021, Bucharest, Romania

*corresponding author: gabriela.musat@umfcd.ro

Manuscript received: January 2019

\begin{abstract}
The aim of this paper was the formulation and preliminary evaluation of colloidal systems with improved mechanical and mucoadhesive properties in order to increase ocular retention time and drug bioavailability. Polymeric mixtures of chitosan $(0.3 \%)$, a pH-sensitive polymer, and poloxamer $407(12 \%, 15 \%, 18 \%)$, thermoresponsive polymer, with bupivacaine hydrochloride $(0.25 \%)$ were prepared. Gelling temperature, wettability, rheological behaviour and in vitro drug release were evaluated. The formulation containing $15 \%$ poloxamer 407 is converted to a colloidal dispersion at $35^{\circ} \mathrm{C}$, the temperature of the ocular surface. Contact angle values of colloidal systems at physiological temperature $\left(35^{\circ} \mathrm{C}\right)$ were lower than those corresponding to formulations at non-physiological temperature $\left(25^{\circ} \mathrm{C}\right)$, indicating a higher spreadability over the ocular surface. Rheological studies have shown pseudoplastic behaviour and the poloxamer concentration increased the viscosity of the formulations. In vitro bupivacaine hydrochloride delivery from colloidal systems revealed that drug release mechanism followed Higuchi model. The colloidal dispersions with chitosan and poloxamer 407 could be viable alternatives to increase the bioavailability of bupivacaine hydrochloride in topical ocular anaesthesia.
\end{abstract}

\section{Rezumat}

Obiectivele acestei lucrări sunt formularea şi evaluarea preliminară a unor sisteme coloidale cu proprietăţi mecanice şi mucoadezive sporite care să asigure un timp de remanenţă crescut la nivel ocular şi o biodisponibilitate a substanţei medicamentoase îmbunătăţite. S-au preparat amestecuri polimerice de chitosan $(0,3 \%)$, un polimer sensibil la variaţia de $\mathrm{pH}$, şi poloxamer $407(12 \%, 15 \%, 18 \%)$, polimer cu proprietăţi termoreversibile, în care a fost încorporată bupivacaină clorhidrat $(0,25 \%)$. Pentru acestea s-au evaluat: temperatura de gelifiere, udabilitatea, comportamentul reologic şi cedarea in vitro a substanţei active. Formularea conţinând $15 \%$ poloxamer $407 \mathrm{~s}$-a transformat într-o dispersie coloidală la $35^{\circ} \mathrm{C}$, temperatura de la suprafaţa oculară. Valorile unghiurilor de contact pentru sistemele coloidale la temperatura fiziologică $\left(35^{\circ} \mathrm{C}\right)$ au fost mai mici decât cele corespunzătoare formulărilor la temperatura nefiziologică $\left(25^{\circ} \mathrm{C}\right)$, fapt ce indică o etalare corespunzătoare pe suprafaţa oculară. Studiile reologice au arătat un comportament pseudoplastic, iar la creşterea concentraţiei de poloxamer s-a înregistrat creşterea vâscozităţii preparatelor. Cedarea in vitro a bupivacainei clorhidrat din sistemele coloidale s-a realizat în conformitate cu modelul Higuchi. Dispersiile coloidale de chitosan şi poloxamer 407 pot reprezenta alternative viabile de creştere a biodisponibilităţii bupivacainei clorhidrat în anestezia topică oculară.

Keywords: chitosan, poloxamer 407, ocular delivery, colloidal systems

\section{Introduction}

One important challenge for the ophthalmic drug administration is to obtain and maintain an optimal concentration of the drug substance in the eye [40]. Conventional eye drops are widely used due to the easy way of administration and compliance of the patient, but they have a drug bioavailability less than 5\% [26]. Physiological barriers such as tear fluid, cornea or nasolacrimal drainage limit the bioavailability of therapeutics in order to protect the eye from the penetration of microorganisms or toxic agents [34]. An attempt to increase ocular retention time through numerous topical pharmaceutical formulations has not been entirely accepted due to disadvantages such as blurred vision (ointments) or low patient compliance (inserts) [21].

An alternative to improve ocular retention time is represented by colloidal systems. There are polymeric colloidal dispersions that undergo phase transition under the influence of temperature in a physiological $\mathrm{pH}$. The main interactions responsible for the solgel transition are physical intermolecular forces such as hydrophobic interactions between polymeric chains [25].

Chitosan is a polysaccharide composed of D-glucosamine and $N$-acetyl-D-glucosamine units linked $\beta$ (1-4). It is obtained by deacetylation of chitin, a 
structural element from exoskeleton of crustaceans such as crab or shrimp and insects cuticles [6, 27]. Chitosan is soluble in acid up to 6.2 due to the protonation of the free amino groups. Acidic solutions exposed to alkaline $\mathrm{pH}$ cause a decrease in apparent charge density with physical gel formation due to the occurrence of hydrogen bonds and hydrophobic interactions [23, 29, 39]. The benefits of including chitosan as an excipient in ophthalmic preparations are good mechanical strength and mucoadhesive character, biocompatibility, biodegradability, nontoxicity, improvement of ocular permeability through paracellular permeation, antimicrobial activity and corneal wound healing effect $[8,20]$. Chitosan exhibits pseudoplastic and viscoelastic behaviour. Mucoadhesiveness is the result of electrostatic interactions between positively charged amine groups of chitosan and negatively charged residues of sialic acid in the mucin structure, enhancing contact time with the ocular surface [5].

Poloxamers (Pluronics ${ }^{\circledR}$ ) are triblock copolymers composed of a hydrophobic polyoxypropylene (PPO) unit flanked by two hydrophilic polyoxyethylene (PEO) chains [2]. Poloxamer 407 known as Pluronic F127 is a non-ionic surfactant with good solubility, low toxicity, compatibility with the cells and fluids of the body. Aqueous solutions of Poloxamer 407 exhibit thermoreversible properties [14]. At concentrations of $18 \%(\mathrm{w} / \mathrm{w})$ or more in aqueous solution, poloxamer 407 become a non-crosslinked gel by exposure to room temperature. Keeping the preparation in the refrigerator enables the ease of administration, but can cause ocular irritation due to low temperature [28]. The main drawback of this polymer is poor mechanical strength that leads to rapid erosion of its matrix [30]. The combination of chitosan with poloxamer 407 results in sterile, non-irritating formulations, and the gels have improved mechanical strength and mucoadhesive character, providing increased contact time with the ocular surface [15]. Bupivacaine hydrochloride is a local anaesthetic with amide structure, slightly soluble in water, with long-lasting action $(2-9 \mathrm{~h})$. Analgesia persists after the regaining of sensation reducing the need for strong analgesics [3]. The mechanism of action is determined by the stabilization of neuronal membranes that prevents the transmission of nerve impulses [9]. Ocular procedures requiring the use of local anaesthetics include cataract surgery, trabeculectomy, pars plana vitrectomy or refractive surgery [32]. Topically applied local anaesthetics block the trigeminal nerve terminations in the cornea and conjunctiva, leaving the intraocular structures of the anterior segment non-anesthetized. Interventions in the iris can irritate the ciliary nerves with discomfort, so association with intracameral anaesthesia is required [22]. In addition to analgesic action, bupivacaine possesses antimicrobial activity on Gram positive and Gram negative bacteria [1, 24].
The United States Pharmacopeia mentions that the systemic absorption rate of bupivacaine hydrochloride is determined by the drug concentration, the route of administration, the vascularization of the administration site and the presence or absence of epinephrine. A diluted concentration of epinephrine (1:200000) with vasoconstrictor action reduces the absorption rate of bupivacaine hydrochloride and prolongs its duration of action [36].

The purpose of this paper was to obtain ophthalmic colloidal systems with improved mechanical and mucoadhesive properties in order to provide enhanced drug bioavailability. In this purpose, polymeric mixtures of chitosan, a $\mathrm{pH}$-sensitive and mucoadhesive polymer, and poloxamer 407, a thermosensitive polymer and gelling agent, were prepared. The same concentration of chitosan $(0.3 \%)$ was used and poloxamer 407 concentration $(12 \%, 15 \%, 18 \%)$ was varied. Bupivacaine hydrochloride was added in a concentration of $0.25 \%$ according to the literature references for topical application $[10,31]$. The formulations were evaluated for gelling temperature, wettability, rheological profiles and in vitro release of the drug substance.

\section{Materials and Methods}

\section{Preparation of polymeric dispersions}

Chitosan (Medium MW 190000 - 310000, DD 75 $85 \%$ ) and Poloxamer 407 were obtained from SigmaAldrich (USA). Bupivacaine hydrochloride was also supplied by Sigma-Aldrich. All other chemicals and solvents used were of analytical grade.

Simulated tear fluid (STF, pH 7.4) was prepared by dissolving the following substances: sodium chloride $0.670 \mathrm{~g}$, sodium bicarbonate $0.200 \mathrm{~g}$, calcium chloride dehydrate $0.008 \mathrm{~g}$ in distilled water (q.s. ad $100 \mathrm{~g}$ ) [16].

Polymeric dispersions based on chitosan and poloxamer were prepared using the "cold method" $[15,30]$. $0.3 \%(\mathrm{w} / \mathrm{w})$ chitosan solutions were prepared by dispersing the corresponding amount in $2 \%(\mathrm{w} / \mathrm{v})$ acetic acid solution under continuous stirring until complete dissolution. Formulations with Poloxamer $407(12 \%, 15 \%, 18 \% \mathrm{w} / \mathrm{w})$ were obtained by dispersing the corresponding amount of poloxamer in distilled water under continuous stirring for $1 \mathrm{~h}$ at room temperature. The partially dissolved poloxamer dispersions were stored in the refrigerator $\left(4^{\circ} \mathrm{C}\right)$ for $24 \mathrm{~h}$ when the entire amount of polymer was completely dissolved. Chitosan/pluronic mixtures were obtained by dispersing the solutions of poloxamer into chitosan solutions under continuous stirring for $1 \mathrm{~h}$. The partially dissolved systems were refrigerated for $24 \mathrm{~h}$ until they were thoroughly mixed. Depending on the concentration of Poloxamer 407 (12\%, 15\%, 18\%), the formulations were coded as A, B, C. Preparation of polymeric mixtures with bupivacaine hydrochloride was achieved by adding $0.25 \%$ drug substance to the 
FARMACIA, 2019, Vol. 67, 4

chitosan/poloxamer dispersions under continuous stirring. The $\mathrm{pH}$ of the formulations was adjusted to 4.5 with $\mathrm{NaOH} 10 \%$ and they were stored at $4{ }^{\circ} \mathrm{C}$ until further use. Each mixture was analysed in triplicate. The composition of the polymeric systems with bupivacaine hydrochloride is shown in Table I.

Table I

Composition of polymeric systems

\begin{tabular}{|l|c|c|c|}
\hline Formulation ingredients & A & B & C \\
\hline P407 (\% w/v) & 12.00 & 15.00 & 18.00 \\
\hline Chitosan (\% w/v) & 0.30 & 0.30 & 0.30 \\
\hline Bupivacaine (w/20 mL) & 0.05 & 0.05 & 0.05 \\
\hline NaOH 10\% (mL) & $2.00 \pm 0.14$ & $2.06 \pm 0.07$ & $1.96 \pm 0.21$ \\
\hline Water q.s. ad mL & 20.00 & 20.00 & 20.00 \\
\hline
\end{tabular}

\section{Visual aspect and gelling temperature}

The gelling capacity for each formulation was determined by adding a volume of the preparation into a transparent vial containing freshly prepared STF and placed in a thermostated water bath. The gel formation was visually evaluated and the phase transition temperature was noted $[17,38]$. Determination of gelling temperature (GT) was performed before and after dilution of each polymeric mixture with STF in 40:7 ratio. It was considered that the average volume of a drop released from an eye drop bottle was approximately $40 \mu \mathrm{L}$ and the available lacrimal fluid volume was $7 \mu \mathrm{L}$ [28]. The visual aspect of the formulations was determined by visual examination alternately on a white or black background under intense light [19].

Contact angle and wettability studies

The wetting capacity was evaluated by measuring the contact angle of the formulations at room temperature and at $35^{\circ} \mathrm{C}$. Contact angles were measured by the sessile drop technique using a CAM 101 Goniometer. The materials to be analysed were coated with glass slides which had water contact angles similar to the ocular surface. $10 \mu \mathrm{L}$ of liquid were placed on the surface of the coated glass slide using a syringe and the drop image was analysed by an automated curvefitting program. Data for contact angles are presented as mean values \pm standard deviations measured in triplicate on three locations on each surface [12, 33]. Rheological studies

Viscosity measurements were performed using a rotational viscometer Fungilab equipped with a low viscosity adaptor (LCP). To simulate physiological conditions, polymeric mixtures were diluted with STF in 40:7 ratio [28]. The formulations were placed in a sample tube and analyzed at physiological temperature $\left(35^{\circ} \mathrm{C}\right)$ by connecting a ThermoHaake
P5 Ultrathermostat. The experimental conditions for rheological analysis were previously described. The rotational speed of the spindle was increased from 1 to 100 and the viscosity of each formulation was measured [13, 27].

In vitro release of bupivacaine hydrochloride

To determine the in vitro release profile of bupivacaine hydrochloride from polymeric mixtures, immersion cells for semisolids (small volume) were adapted to a dissolution equipment such as USP2 paddle method (Hanson Vision ${ }^{\circledR} \mathrm{G} 2$ Classic $6^{\mathrm{TM}}$, USA) with flat bottom $150 \mathrm{~mL}$ dissolution vessels. $1 \mathrm{~mL}$ of sample was weighed and placed in the compartment of the enhancer cells. Previously, filter membranes with $0.45 \mu \mathrm{m}$ pore size and $25 \mathrm{~mm}$ of cellulose acetate provided by Sartorius Biolab Products were soaked for $8 \mathrm{~h}$ in phosphate buffer ( $\mathrm{pH}$ 7.4), then placed on the samples surface. The enhancer cells were assembled as per the manufacturer's instructions. The cells were suspended in the dissolution vessels containing 100 $\mathrm{mL}$ of phosphate buffer medium and the stirring rate was maintained at $150 \mathrm{rpm}$. The apparatus was pre-set at physiological temperature $\left(35^{\circ} \mathrm{C}\right)$. At predetermined time intervals $(5,15,30,45,60,75$, $90,120,150 \mathrm{~min}), 1 \mathrm{~mL}$ sample of the release medium was withdrawn and replenished with fresh medium. The concentration of bupivacaine hydrochloride was spectrophotometrically assessed at $262 \mathrm{~nm}[4,9,18,35]$.

\section{Results and Discussion}

Table II shows the visual appearance of each sample at room temperature $\left(25^{\circ} \mathrm{C}\right), \mathrm{pH}$, as well as phase transition temperature (PCT) for polymeric mixtures with bupivacaine hydrochloride before and after dilution with STF.

Table II

Physical properties of the polymeric systems

\begin{tabular}{|c|c|c|c|c|}
\hline Formulation & Clarity & $\mathbf{p H}$ & PCT before dilution $\left.^{\circ}{ }^{\circ} \mathbf{C}\right)$ & PCT after dilution $\left.^{(}{ }^{\circ} \mathbf{C}\right)$ \\
\hline A & Clear & $4.51 \pm 0.01$ & $37.06 \pm 0.07$ & $38.40 \pm 0.35$ \\
\hline B & Clear & $4.53 \pm 0.02$ & $33.33 \pm 0.21$ & $35.40 \pm 0.14$ \\
\hline C & Not clear & $4.54 \pm 0.05$ & $25.36 \pm 0.28$ & $28.80 \pm 0.07$ \\
\hline
\end{tabular}

It was visually observed that formulations with poloxamer $40712 \%$ (series A) and 15\% (series B) were clear, transparent at room temperature. The series with $18 \%$ poloxamer (series C) was slightly 
opalescent at room temperature. This was in accordance with the literature which mentioned that formulations with poloxamer $18 \%$ were converted from low viscosity solutions to non-crosslinked gels $[7,38]$.

Regarding the gelling temperature (GT), this was influenced by the concentration of poloxamer 407 . The ideal phase transition temperature should be between $25^{\circ} \mathrm{C}$ and $35^{\circ} \mathrm{C}$, the temperature at the ocular surface. Due to this fact, poloxamer was chosen as a gelling agent [15]. The reversible thermogelling phenomenon is the consequence of hydrophobic interactions between polymer chains. At low temperatures, the molecules are surrounded by a hydration layer, while the increase in temperature results in breakage of the hydrogen bonds between the aqueous solvent and the hydrophilic chains of the polymer. Increasing the temperature determines the aggregation of the chains with formation of a micelle structure due to the dehydration of the hydrophobic units of polyoxypropylene [11, 14]. The increase in poloxamer concentration resulted in GT reduction before and after dilution with STF. After dilution with STF, all formulations showed a translucent clear matrix and a superior PCT value. In the case of series $A$, the concentration of poloxamer 407 was relatively low, so it was not sufficient for a rapid gelling and PCT values were the highest. Formulations with poloxamer $40715 \%$ were converted to a colloidal solution after dilution at $35^{\circ} \mathrm{C}$, the temperature of the ocular surface. The visual appearance of polymeric mixtures before and after gelation is shown in Figure 1.

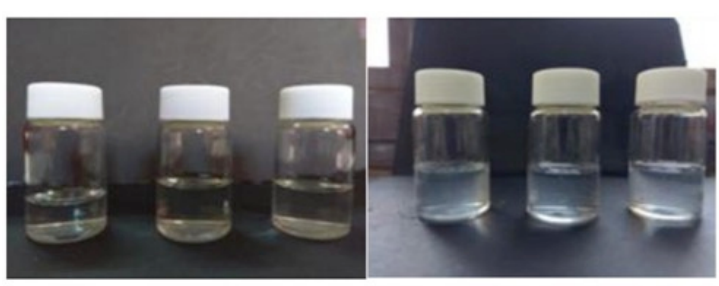

(a)

(b)

Figure 1.

Polymeric mixtures before (a) and after gelling (b)

Gelling temperature of polymeric mixtures before and after dilution with STF is illustrated in Figure 2.

The amino groups of chitosan provide an increased charge density that can affect the formation of water channels around the polyoxypropylene units [37]. Gratieri et al. showed that a chitosan concentration between $0.5 \%$ and $1.5 \%$ did not significantly affect sol-gel transition of poloxamer [15]. Thus, the poloxamer gelling capacity was not influenced by the $0.3 \%$ chitosan concentration. However, chitosan, whose solubility is affected by an increase in $\mathrm{pH}$ and the presence of water, can also contribute to the occurrence of turbidity after dilution.

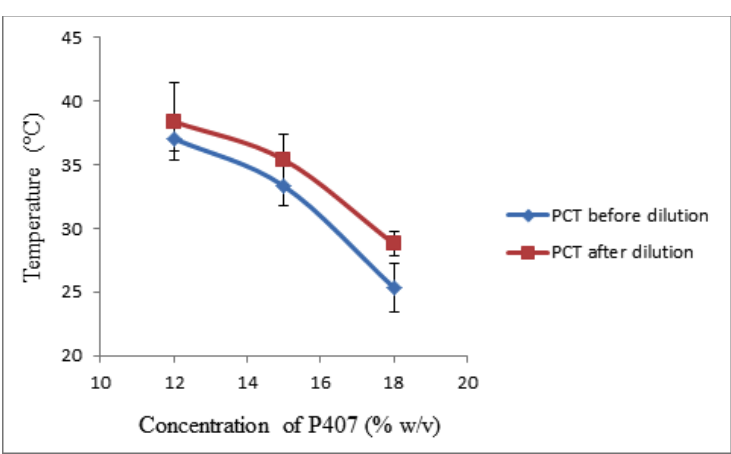

Figure 2.

Phase Change Temperature (PCT) of chitosan/ poloxamer mixtures before and after dilution

The contact angle (CA) values for polymeric mixtures at room temperature are presented in Table III.

Table III

Contact angle values of formulations at nonphysiological conditions $\left(25^{\circ} \mathrm{C}\right)$

\begin{tabular}{|c|c|}
\hline Formulation & CA $\left.^{\circ}{ }^{\circ}\right)$ \\
\hline A & $16.97 \pm 0.75$ \\
\hline B & $29.36 \pm 0.95$ \\
\hline C & $32.44 \pm 1.83$ \\
\hline
\end{tabular}

Table IV highlights the contact angle values for colloidal dispersions with chitosan and poloxamer 407 at $35^{\circ} \mathrm{C}$.

Table IV

Contact angle for colloidal systems at physiological

\begin{tabular}{|c|c|}
\multicolumn{1}{c}{} & conditions $\left(3{ }^{\circ}\right.$ \\
\hline Formulation & $\mathbf{C A}\left({ }^{\circ}\right)$ \\
\hline $\mathbf{A}$ & $18.32 \pm 0.38$ \\
\hline B & $28.01 \pm 0.90$ \\
\hline $\mathbf{C}$ & $27.99 \pm 1.33$ \\
\hline
\end{tabular}

Increasing polymer concentration and enhancing viscosity, the measured contact angle values slightly increased; consequently, spreading of the formulations on the surface decreased. Figure 3 shows polymeric mixtures drops images from the optical contact angle goniometer for the series A, B, C.

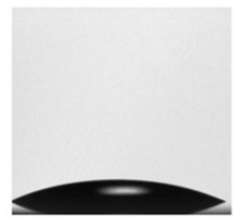

$\mathbf{A}$

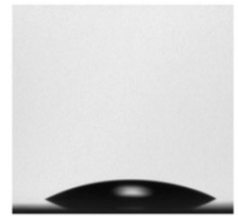

B

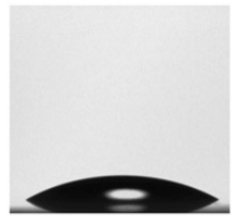

C
Figure 3.

Images of polymeric mixtures drops for series A, B, C

Contact angle values of colloidal dispersions at $35^{\circ} \mathrm{C}$ are lower than those corresponding to formulations at $25^{\circ} \mathrm{C}$, indicating a higher spreadability over the ocular surface. The colloidal systems drops images from the optical contact angle goniometer for the series A, B, C at $35^{\circ} \mathrm{C}$ are shown in the Figure 4 . 


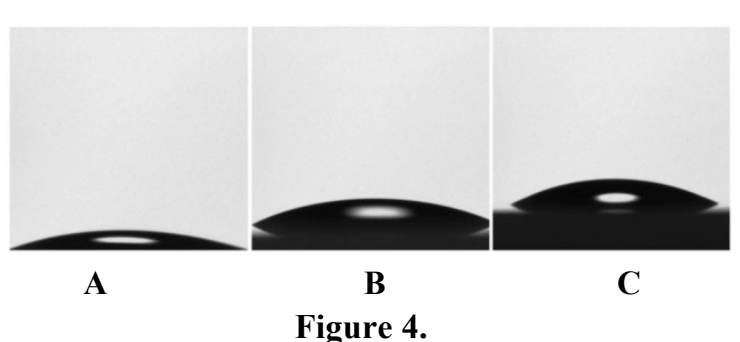

Images of colloidal systems drops for the series A, $\mathrm{B}, \mathrm{C}$

The formulations with low contact angle values (those from series A-poloxamer $10 \%$ and from series B- poloxamer 15\%) spread rapidly and form a flat, transparent monolayer that enables clear vision without blurring and disturbing observation of anterior segment or retinal structures, so important for performing intraocular procedures. The ocular surface was found to be hydrophilic due to tear film and hence the improved hydrophilic properties of thermogelling systems allow them to make proper contact with cornea and conjunctiva.

Evaluation of rheological profiles for the analysed systems was performed at $35^{\circ} \mathrm{C}$.

The rheological curves recorded as viscosity versus shear rate are given in Figure 5.

The viscosity of the thermogelling dispersions was proportionally with the poloxamer concentration. As can be noticed from Figure 5, the viscosity decreased with the shear rate increase, which showed pseudoplastic flow behaviour. The pseudoplastic flow was due to breakage of physical bonds between polymer molecules and alignment of disordered molecules in the direction of flow [13]. The addition of chitosan to the aqueous solutions of poloxamer 407 has led to improve the viscosity and elasticity of the preparations.

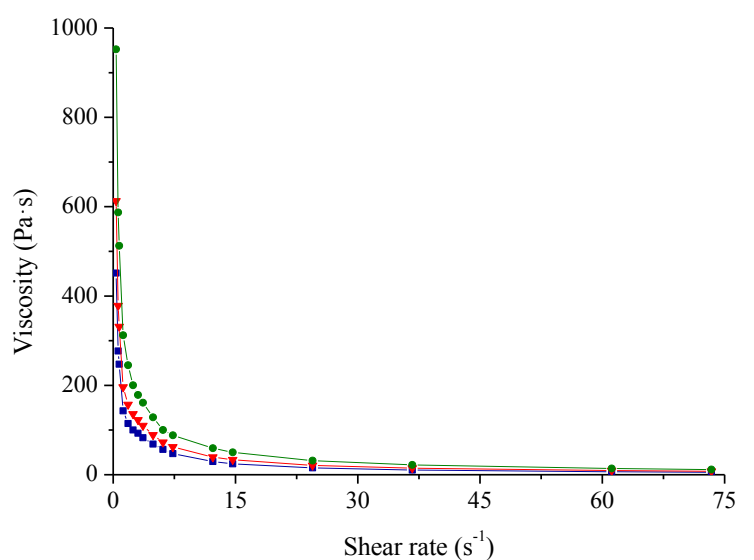

Figure 5.

Plots of viscosity as a function of shear stress for colloidal systems

The rheological data were fitted according to Power law model (eq. 1):

$$
\frac{\mathrm{Wt}-\mathrm{Wd}}{\mathrm{Wd}} \mathrm{g} / \mathrm{g} \text {, }
$$

where, $\mathrm{m}$ is the viscosity for shear rate $1 \mathrm{~s}^{-1}$ and $\mathrm{n}-$ flow index.

The values of the rheological parameters characteristic for the analysed systems are shown in Table V.

Values of the rheological parameters characteristic for the analysed systems

\begin{tabular}{|c|c|c|c|}
\hline Tested samples & $\mathbf{~ m}$ & $\mathbf{n}$ & $\mathbf{R}^{\mathbf{2}}$ \\
\hline Serie A & $195.701 \pm 3.38$ & $0.789 \pm 0.02$ & $0.9930 \pm 0.0005$ \\
\hline Serie B & $267.497 \pm 4.50$ & $0.795 \pm 0.04$ & $0.9945 \pm 0.0006$ \\
\hline Serie C & $405.201 \pm 6.52$ & $0.815 \pm 0.05$ & $0.9969 \pm 0.0008$ \\
\hline
\end{tabular}

The influence of poloxamer concentration on the cumulative drug released bupivacaine hydrochloride percentage as a function of time is represented in Figure 6.

The kinetic data respected the Higuchi model, the values of the determination coefficients being higher than 0.99 (Table VI). The quantification of the release kinetics of bupivacaine hydrochloride from the polymeric mixtures was evaluated by the diffusion coefficient parameter:

$$
D=\frac{q^{2} \cdot \pi}{4 \cdot C_{0}^{2} \cdot t},
$$

where, $\mathrm{D}$ is the diffusion coefficient of the active substance $\left(\mathrm{cm}^{2} / \mathrm{min}\right), \mathrm{q}-$ the amount of the drug released on the surface unit of the membrane $\left(\mathrm{g} / \mathrm{cm}^{2}\right)$, $\mathrm{C}_{0}$ - the initial concentration of the active substance $(\mathrm{g} / \mathrm{mL})$ and $\mathrm{t}-$ the time of release $(\mathrm{min})$.

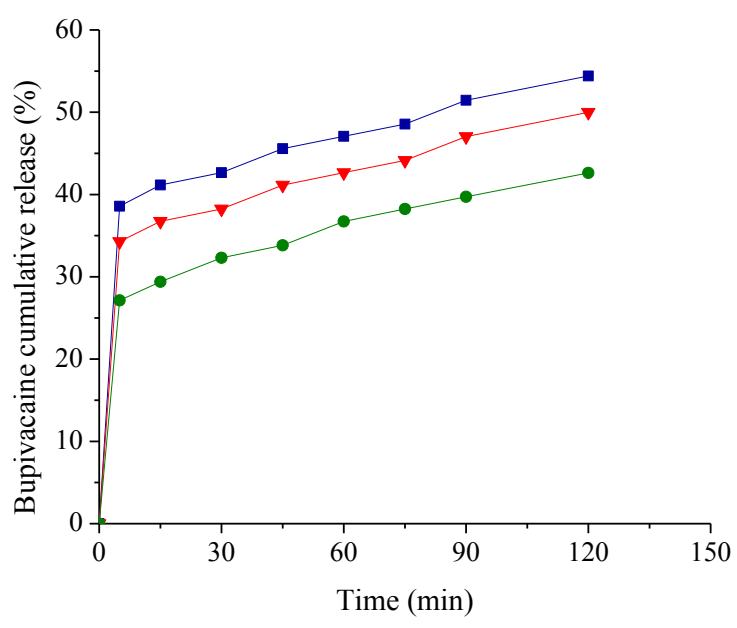

Figure 6.

Cumulative release profiles of bupivacaine hydrochloride from colloidal systems as a function of time 
FARMACIA, 2019, Vol. 67, 4

Table VI illustrates the values obtained for the kinetic parameter mentioned above. An increase in poloxamer concentration by 6 units (from $12 \%$ to $18 \%$ ) resulted in a decrease of the diffusion coefficient, after gelling, with $74.4 \%$ (from $4.22 \cdot 10^{7}$ $\left(\mathrm{cm}^{2} / \mathrm{s}\right)$ to $3.14 \cdot 10^{7}\left(\mathrm{~cm}^{2} / \mathrm{s}\right)$ and consequently a reduction in the release rate of bupivacaine hydro- chloride. A higher poloxamer concentration represented a real barrier to bupivacaine hydrochloride release due to lowering the number and size of water channels and the appearance of the micelles. Chitosan has contributed to the prolonged release of the active substance by formation of micelle junction points with poloxamer.

Table VI

Diffusion coefficient values, using a USP2 device, the correlation coefficient specific to Higuchi model

\begin{tabular}{|c|c|c|}
\hline \multirow{2}{*}{$\begin{array}{c}\text { Delivery } \\
\text { system }\end{array}$} & \multicolumn{2}{|c|}{ System responses } \\
\cline { 2 - 3 } & Diffusion coefficient $\mathbf{D} \cdot \mathbf{1 0}^{\mathbf{7}} \mathbf{( \mathbf { c m } ^ { 2 } / \mathbf { s } )}$ & Determination coefficient (Higuchi model) \\
\hline $\mathrm{A}$ & $4.22 \pm 0.11$ & $0.9935 \pm 0.0003$ \\
\hline $\mathrm{B}$ & $3.80 \pm 0.09$ & $0.9940 \pm 0.0006$ \\
\hline $\mathrm{C}$ & $3.14 \pm 0.21$ & $0.9913 \pm 0.0008$ \\
\hline
\end{tabular}

\section{Conclusions}

This paper aims to formulate and evaluate colloidal dispersions with chitosan and poloxamer 407 as promising delivery systems in ocular surgery. The topical anaesthetic bupivacaine hydrochloride $(0.25 \%)$ was successfully incorporated in thermoreversible polymeric systems with the same concentration of chitosan $(0.3 \%)$ and three different concentrations of poloxamer $407(12 \%, 15 \%, 18 \%)$. The formulation with $15 \%$ poloxamer exhibited a gelling temperature at $35^{\circ} \mathrm{C}$ that is the temperature at the ocular surface. Contact angle values of colloidal mixtures at physiological conditions are lower than those corresponding to polymeric dispersions at nonphysiological conditions. They spread rapidly and form a flat, transparent monolayer that enables clear vision without blurring and disturbing observation of anterior segment or retinal structures. The rheological profiles showed a pseudoplastic flow for all the three types of formulations. The increase in poloxamer concentration resulted in a lowering of the diffusion coefficient after gelling and a decrease in the bupivacaine hydrochloride release rate which was performed according to the Higuchi model. In conclusion, these thermogelling systems could be promising alternatives to ocular drug delivery, improving the bioavailability of bupivacaine hydrochloride in the eye.

\section{Acknowledgement}

This paper was financially supported by "Carol Davila" University of Medicine and Pharmacy through Contract no. 23PFE/17.10.2018 funded by the Ministry of Research and Innovation within PNCDI III, Program 1 - Development of the National RD system, Subprogram 1.2 - Institutional Performance - RDI excellence funding projects.

\section{References}

1. Adler DMT, Damborg P, Verwilghen DR, The antimicrobial activity of bupivacaine, lidocaine and mepivacaine against equine pathogens: An investigation of 40 bacterial isolates. Vet J., 2017; 223: 27-31.

2. Agrawal AK, Das M, Jain S, In situ gel systems as "smart" carriers for sustained ocular drug delivery. Exp Opin Drug Deliv., 2012; 9(4): 383-402.

3. Balakrishnan C, Ebenezer V, Dakir A, Kumar S, Prakash D, Bupivacaine versus lignocaine as the choice of local anesthetic agent for impacted third molar surgery a review. J Pharm Bioallied Sci., 2015; 7(1): 230-233.

4. Bao Q, Shen J, Jog R, Zhang C, Newman B, Wang $\mathrm{Y}$, Choi $\mathrm{S}$, Burgess DJ, In vitro release testing method development for ophthalmic ointments. Int J Pharm., 2017; 526(1-2): 145-156.

5. Başaran E, Yazan Y, Ocular application of chitosan. Exp Opin Drug Deliv., 2012; 9(6): 701-712.

6. Bhattarai N, Gunn J, Zhang M, Chitosan-based hydrogels for controlled, localized drug delivery. Adv Drug Deliv Rev., 2010; 62: 83-99.

7. Bhoyar BS, Agnihotrh VV, Bodhankar MM, A novel thermoreversible phase transition system with flux enhancers for opthalmic application. Int $J$ Pharm Pharm Sci., 2011; 3(4): 367-370.

8. Cheung RC, Ng TB, Wong, JH, Chan, WY, Chitosan: An Update on Potential Biomedical and Pharmaceutical Applications. Mar Drugs, 2015; 13(8): 5156-5186.

9. Corciova A, Spectrophotometric method for determination of bupivacaine hydrochloride in pharmaceutical preparations. Eur Chem Bull., 2012; 2(8): 554-557.

10. Dobrescu D, Negreş S, Dobrescu L, McKinnon R, Memomed 2017 Memoir of Allopathic Pharmacology, Ed. Universitară, Bucharest, 2017; 839, (available in Romanian).

11. Fakhari A, Corcoran M, Schwarz A, Thermogelling properties of purified poloxamer 407. Heliyon, 2017; 3(8): 1-26.

12. Ghica MV, Albu MG, Kaya DA, Popa L, Öztürk Ş, Rusu LC, Dinu-Pîrvu C, Chelaru C, Albu L, Merghea A, Nitipir C, The effect of lavandula essential oils on release of niflumic acid from collagen hydrolysates. Kor J Chem Eng., 2016; 33(4): 1325-1330.

13. Ghica MV, Hîrjău M, Lupuleasa D, Dinu-Pîrvu CE, Flow and thixotropic parameters for rheological characterization of hydrogels. Molecules, 2016; 21(6): 786: 1-17. 
FARMACIA, 2019, Vol. 67, 4

14. Giuliano E, Paolino D, Fresta M, Cosco D, Mucosal Applications of Poloxamer 407-Based Hydrogels: An Overview. Pharmaceutics, 2018; 10(3): 1-26.

15. Gratieri T, Gelfuso GM, Rocha EM, Sarmento VH, de Freitas O, Lopez RF, A poloxamer/chitosan in situ forming gel with prolonged retention time for ocular delivery. Eur J Pharm Biopharm., 2010; 75: 186-193.

16. Gupta H, Jain, S, Mathur R, Mishra P, Mishra AK, Velpandian T, Sustained ocular drug delivery from a temperature and $\mathrm{pH}$ triggered novel in situ gel system. Drug Deliv., 2007; 14: 507-515.

17. Gupta S, Vyas SP, Carbopol/Chitosan based $\mathrm{pH}$ triggered in situ gelling system for ocular delivery of timolol maleate. Sci Pharm., 2010; 78(4): 959-976.

18. Kadam AT, Jadhav RI, Salunke PB, Kadam SS, Design and evaluation of modified chitosan based in situ gel for ocular drug delivery. Int J Pharm Pharm Sci., 2017; 9: 87-91.

19. Karataş A, Boluk A, Algan AH, Poloxamer/Chitosan In situ Gelling System for Ocular Delivery of Ofloxacin. Curr Drug Ther., 2014; 9: 219-225.

20. Krtalić I, Radošević S, Hafner A, Grassi M, Nenadić M, Cetina-Cižmek B, Filipović-Grčić J, Pepić I, Lovrić J, D-Optimal design in the development of rheologically improved in situ forming ophthalmic gel. J Pharm Sci., 2018; 107: 1562-1571.

21. Makwana SB, Patel VA, Parmar SJ, Development and characterization of in situ gel for ophthalmic formulation containing ciprofloxacin hydrochloride. Results Pharm Sci., 2015; 6: 1-6.

22. Malik A, Efficacy and performance of various local anesthesia modalities for cataract surgery. $J$ Clin Exp Ophthalmol., 2013; 1: 1-13.

23. Muţ AM, Vlaia L, Coneac G, Olariu I, Vlaia V, Stănciulescu C, Mitu MA, Szabadai Z, Lupuliasa D, Chitosan/HPMC-based hydrogels containing essential oils for topical delivery of fluconazole: Preliminary studies. Farmacia, 2018; 66(2): 248-256.

24. Neuwersch S, Köstenberger M, Sorschag S, Ilias W, Likar R, Antimicrobial Activity of Lidocaine, Bupivacaine, Mepivacaine and Ropivacaine on Staphylococcus epidermidis, Staphylococcus aureus and Bacillus subtilis. Open Pain J., 2017; 10(1): 1-4.

25. Panainte AD, Popa G, Pamfil D, Butnaru E, Vasile C, Mititelu Tarțău L, Gafițanu C, In vitro characterization of polyvinyl alcohol/ chitosan hydrogels as modified release systems for bisoprolol. Farmacia, 2018; 66(1): 44-48.

26. Patel A, Cholkar K, Agrahari V, Mitra AK, Ocular drug delivery systems: An overview. World $J$ Pharmacol., 2013; 2(2): 47-64.
27. Popa L, Ghica MV, Dinu-Pîrvu CE, Periodontal chitosan-gels designed for improved local intrapocket drug delivery. Farmacia, 2013; 61(2): 240250.

28. Qian Y, Wang F, Li R, Zhang Q, Xu Q, Preparation and evaluation of in situ gelling ophthalmic drug delivery system for methazolamide. Drug Dev Ind Pharm., 2010; 36(11): 1340-1347.

29. Racine L, Texier I, Auzély-Velty R, Chitosan-based hydrogels: Recent design concepts to tailor properties and functions. Polym Int., 2017; 66: 981-998.

30. Rajalakshmi R, Padmaja C, Radhika N, Kumuda P, Pavan Kumar P, Ujjwala B, Vinesha V, Formulation and Assessment of Gemifloxacin Mesylate Ocular In situ Gelling System. Int Res J Pharm., 2013; 4(10): 33-38.

31. RxList, www.rxlist.com/marcaine-drug..

32. Shah HR, Reichel E, Busbee BG, A novel lidocaine hydrochloride ophthalmic gel for topical ocular anesthesia. Local Regional Anesthesia, 2010; 3: 57-63.

33. Suri S, Banerjee $\mathrm{R}$, In vitro evaluation of in situ gels as short term vitreous substitutes. J Biomed Mater Res A., 2006; 79(3): 650-664.

34. Tsai CH, Wang PY, Lin IC, Huang H, Liu GS, Tseng CL, Ocular drug delivery: Role of degradable polymeric nanocarriers for ophthalmic application. Int J Mol Sci., 2018; 19(9): 2830-2850.

35. United States Pharmacopeia 2015 USP 38/National Formulary 2014 NF 33, Semi-solid drug productsperformance tests, Volume 1, Deutscher Apotheker Verlag, Stuttgart, 2014; 1625.

36. United States Pharmacopeia 2015 USP 38/National Formulary 2014 NF 33, Bupivacaine hydrochloride and epinephrine injection, Volume 2, Deutscher Apotheker Verlag, Stuttgart, 2014; 2485.

37. Ur-Rehman T, Tavelin S, Gröbner G, Chitosan in situ gelation for improved drug loading and retention in poloxamer 407 gels. Int J Pharm., 2011; 409(1-2): 19-29.

38. Varshosaz J, Tabbakhian M, Salmani Z, Designing of a Thermosensitive Chitosan/Poloxamer In situ Gel for Ocular Delivery of Ciprofloxacin. Open Drug Deliv J., 2008; 2: 61-70.

39. Wu QX, Lin DQ, Yao SJ, Design of Chitosan and Its Water Soluble Derivatives-Based Drug Carriers with Polyelectrolyte Complexes. Mar Drugs, 2014; 12(12): 6236-6253.

40. Wu Y, Liu Y, Li X, Kebebe D, Zhang B, Ren J, Lu J, Li J, Du S, Liu Z, Research progress of in-situ gelling ophthalmic drug delivery system. AJPS, 2019; 14(1): 1-15. 